\title{
Redressing Risk Oversight Failure in UK and US Listed Companies: Lessons from the RBS and Citigroup Litigation
}

\author{
Marc T. Moore ${ }^{1}$
}

Published online: 26 September 2017

(C) The Author(s) 2017. This article is an open access publication

\begin{abstract}
In the decade since the onset of the 2007-2008 financial crisis, there have been numerous calls for the directors of failed or rescued banks to be held liable for the significant losses that these collapses inflicted on investors and the general public. In the UK, the high-profile RBS Rights Issue Litigation has come to represent something of a fulcrum of domestic concerns in this regard. Notwithstanding their mixed results, securities law actions alleging disclosure failure have been a fairly popular avenue of attempted redress for investors who were burned in the crisis, as exemplified most pertinently by the successful US litigation emanating from the implosion of Citigroup in 2008. By contrast, directors' duties actions premised on alleged risk oversight failure in collapsed banks have enjoyed only limited success in the United States, and no real success whatsoever in the UK. This is a remarkable fact, given that the director's corporate law duty of care would prima facie seem the most direct and overt means of redressing investor losses in such instances. The implication is that in UK (as in US) listed companies today, the duty of care is being
\end{abstract}

I am grateful to the Leverhulme Trust for funding the time involved in the researching and writing of this article, and also to Cambridge 3CL and Jonathan Lau for research assistance. My work on this project was further supported by receipt of a Ross Parsons Visitorship from Sydney Law School in March 2016, which I am likewise grateful for. I am particularly indebted to Christopher Bruner, Brian Cheffins and Harry McVea for reading and insightfully commenting on earlier versions of this article, and also to the EBOR reviewers for their constructive criticisms and recommendations. Earlier versions of this article were presented at the University of Edinburgh (November 2015), Victoria University of Wellington (February 2016) and the University of Sydney (March 2016). I am thankful for comments and observations received from participants at all of these events, and especially to Bob Austin, Emilios Avgouleas, Greg Golding, Jennifer Hill, Parker Hood, Kym Sheehan, Matteo Solinas and Victoria Stace. The opinions expressed, together with any outstanding errors, are those of the author alone.

Marc T. Moore

mtm48@cam.ac.uk

1 Reader in Corporate Law and Fellow of Murray Edwards College, University of Cambridge, Cambridge, UK 
progressively usurped in this regard by alternative securities law mechanisms, rendering corporate law increasingly redundant as a meaningful lever of director accountability.

Keywords Corporate law · Directors' duties · Risk oversight failure · Securities litigation · United Kingdom · United States

\section{Introduction}

As we approach the tenth anniversary of the onset of the global financial crisis, it seems a fitting occasion to take stock of the lessons learned. Of these there have undoubtedly been many. One particular maxim that stands out is never to trust corporate law in a crisis. Indeed, in the UK there would appear to be a continuing general perception that despite a raft of lengthy public enquiries and complex regulatory reforms since 2008, the perceived protagonists of the principal domestic banking collapses have-to use a somewhat apt term in the circumstances-largely 'got off Scot-free' in the sense of avoiding meaningful legal censure for their disastrous decisions at the time.

However, recent legal developments in the UK suggest that this chapter of history might not quite be over yet. The ongoing (at time of writing) RBS Rights Issue Litigation ${ }^{1}$ represents the first recorded instance in the UK of a large group of investors combining their resources to launch a securities lawsuit in connection with a high-profile corporate internal control failure. In this regard, its alleged facts are broadly similar to those of a 2009 securities law action brought, albeit unsuccessfully, against the same bank and its former management in the United States. ${ }^{2}$ Both the current $R B S$ case and the roughly contemporaneous Lloyds Banking Group Litigation $^{3}$ demonstrate that, at least in instances of extraordinary investor loss, sufficient private incentives will sometimes exist to seek collective redress for risk oversight failures in UK listed companies, despite the considerable practical challenges involved.

However, a curious feature of the above cases is that they do not concern corporate law issues in the orthodox sense of the term. Whereas the $R B S$ litigation essentially centres on purported disclosure violations by the bank and its senior officers in the context of a 2008 public share placement, the Lloyds case concerns questions of general private law with respect to a fiduciary's obligation to provide adequate information. In other words, the key investor actions emanating from the UK banking collapses have derived from what are fundamentally disclosure based concerns under securities or private law, rather than orthodox corporate law

\footnotetext{
${ }^{1}$ See RBS Rights Issue Litigation, Re; Greenwood v. Goodwin; Trustees of the Mineworkers' Pension Scheme Ltd v. Royal Bank of Scotland Group plc (2014) EWHC 227, analysed in Sect. 7 below.

${ }^{2}$ See In re Royal Bank of Scotland Group plc Securities Litigation, 09 Civ. 300 (SDNY); In re Royal Bank of Scotland Group plc Securities Litigation, 09 Civ. 300 [2011] 002 IITRALR (Jan 11, 2011), 765 F.Supp.2d 327 (S.D.N.Y. 2011), analysed in Sect. 6 below.

3 See Sharp v. Blank [2015] EWHC 3220.
} 
complaints regarding directors' allegedly negligent risk oversight. For corporate law scholars in the UK this is an interesting but also somewhat discomforting fact, given that the director's duty of care is prima facie the most direct and overt legal means of rectifying investor losses resulting from serious mismanagement or internal control failure.

Insofar as US listed companies are concerned today, the above observations are not especially novel. Indeed, in the United States it is now widely recognised that securities law actions based on managerial misinformation in connection with board oversight failure, rather than corporate law negligence claims alleging board oversight failure per se, represent investors' most practicable means of obtaining some sort of retrospective redress for public company mismanagement. As will be discussed below, this is demonstrated most pertinently by the controversial Citigroup litigation that took place before both the Delaware (corporate law) ${ }^{4}$ and federal (securities law) $)^{5}$ courts over the course of 2009-2012. However, less acknowledged is the fact that misinformation-based actions under securities law are also becoming the preferred avenue of redress ${ }^{6}$ for investors who incur losses as a result of high-level internal control failings in UK listed ${ }^{7}$ companies today. Accordingly, this article posits that-as regards public companies at least-the director's corporate law duty of care will become progressively redundant as an effective mechanism of director accountability in the UK, a development that already seems to have occurred to a large extent in the United States.

The article is structured as follows. In Sects. 2 and 3 I highlight the apparent futility of the director's duty of care in - respectively - the UK and United States in the aftermath of the 2007-2008 financial crisis, focussing in particular on the respective conclusions of the (then) UK Financial Services Authority (FSA) and Delaware Court of Chancery to the effect that the former boards of the failed banks RBS and Citigroup - despite each making a catalogue of poor business decisionshad done nothing to justify the attribution of negligence liability on the part of any of their individual members. In Sect. 4 I assess the key strands of academic literature that highlight how, in the United States at least, securities law misinformation claims have increasingly come to usurp the traditionally perceived function of corporate law negligence claims in redressing the mismanagement of

\footnotetext{
${ }^{4}$ On this, see Sect. 3.

5 On this, see Sect. 5.

6 As will be explained further below, the term 'redress' as used in this context should not necessarily be interpreted in the orthodox civil sense of denoting the imposition of direct personal-pecuniary liability on defendant corporate officers. Rather, in its (broader) presently-understood sense the meaningful 'redress' of corporate mismanagement can arguably be achieved — albeit in a more limited and reflexive way-by means of other negative outcomes which typically follow either directly or indirectly from investors' private enforcement activities in appropriate cases. On this, see nn. 59-62 below and accompanying text.

7 The author's dual usage in this paper of the terms 'public' and 'listed' companies is an intentional rather than haphazard trait, intended to denote the fact that whilst the principal bodies of securities regulation (including applicable disclosure and anti-fraud rules) are applicable only to those companies with an official main market listing in the relevant jurisdiction, the corporate governance and control problems that tend to beset such firms are common to all Anglo-American public companies (listed or otherwise) featuring a characteristic widely-held ownership base. On these problems generally, see Berle and Means (1932).
} 
public companies. In Sects. 5 and 6 I illustrate this phenomenon by reference to what are arguably two of the most pertinent post-crisis examples of US federal securities law being used to redress bank investors' losses in risk oversight-related scenarios, namely the Citigroup and RBS (US) Securities Litigation cases respectively. In Sect. 7 I suggest that the subsequent RBS Rights Issue Litigation presently before the English High Court provides tentative indications of a similar pattern occurring in the UK today, irrespective of the ultimate outcome of those proceedings.

\section{The Futility of the Director's Duty of Care in the UK after the Crisis}

It is common knowledge that the 2007-2008 financial crisis witnessed arguably the most serious catalogue of corporate internal control lapses in history, especially in the US and UK banking sectors. Most prominent amongst these were the cataclysmic implosions of Lehman Bros, AIG and Citigroup in the US, and also the comparably seismic (domestically at least) collapses of RBS, HBOS and Northern Rock in the UK. Although the circumstances precipitating these extraordinary events were many, varied and complex, it has been well documented in numerous authoritative analyses of the crisis that both poor management and corporate governance failure in the firms concerned were material operating factors. 8

Notwithstanding, it has been noted that corporate law-and, in particular, the director's duty of care-has remained curiously silent with respect to these affairs. Indeed, on a practical level at least, questions of directorial negligence under corporate law seemed to be given limited serious consideration in the aftermath of the crisis. As Joan Loughrey (writing in 2012) has observed, '[i]t is striking that no significant litigation has yet emerged against the directors of banks and financial institutions for breaching their duties, despite the disastrous management that was uncovered by the crisis'. 9 Moreover, according to Loughrey:

[g]iven the level of shareholder anger at the scale of the losses incurred by institutions during the crisis, and given that various inquiries into the crisis identified missteps by bank directors, then arguably if ever there was going to be shareholder litigation against directors for breaching their duties to their companies, it would have materialized against the directors of banks. ${ }^{10}$

In particular, it was deemed that the directors of the failed (and subsequently nationalised) British retail bank Northern Rock, despite having permitted the perpetuation of a highly risky business model predicated on the continuing availability

\footnotetext{
${ }^{8}$ See, e.g. Financial Services Authority (FSA) (2011), pp 39-40; Financial Conduct Authority and Prudential Regulation Authority (FCA/PRA) (2015), pp 29-31; Parliamentary Commission on Banking Standards (2013), pp 18-22; House of Commons Treasury Committee (2008), pp 18-19; Walker (2009), p 26; Tomasic (2008); Lowry et al. (2015), pp 81-87. Although for a counter-argument to this proposition (in respect of relevant events in the US at least), see Cheffins (2009).

9 Loughrey (2012a), p 1.

${ }^{10}$ Ibid., p 7.
} 
of short-term wholesale funding, had done nothing to justify the commencement of subsequent negligence proceedings against them. ${ }^{11}$ Likewise, the Enforcement Division of the Financial Services Authority [now the Financial Conduct Authority (FCA)] -in its investigation into possible grounds for misconduct arising out of the collapse of RBS-concluded that there were no grounds for bringing disciplinary proceedings against any of the bank's former directors for negligence. This was despite the Authority's damning exposition of a number of aspects of firm-specific mismanagement and governance failure in RBS during the years immediately preceding the crisis. ${ }^{12}$

Most pertinent amongst the revealed aspects of mismanagement at RBS were the bank's relatively high (by general industry standards) degree of leverage and liquidity risk exposure; the overly aggressive expansion of its investment banking operations, particularly into activities that rendered the bank's balance sheet highly vulnerable to any subsequent downturn in the US sub-prime residential mortgage market; and also its ill-considered 2007 acquisition of ABN AMRO, which rapidly increased RBS's overall degree of indebtedness while further amplifying its group-wide level of exposure to highly risky mortgage-backed financial products. Notable exposed corporate governance failings at RBS during the relevant time period, meanwhile, included an apparent lack of board-level knowledge and understanding of many of the group's more complex and opaque investment banking activities, coupled with a general management and boardroom culture that was seemingly averse to the constructive challenge of senior executive opinion, and - in particular - the initiatives of its then-CEO Fred Goodwin. ${ }^{13}$

As a public enforcement body (rather than shareholder of the bank), the thenFSA did not in itself have any standing to raise a legal action against RBS's directors for breach of their general corporate law duties per se. However, the FSA/ FCA's Statement of Principles for Approved Persons do-and during the relevant time period did-require that an Approved Person (a category which includes UK banking company directors) must (inter alia) act with due care, skill and diligence in carrying out his functions. ${ }^{14}$ Failure to do so will expose the relevant person to potential disciplinary enforcement action by the FSA/FCA on grounds of misconduct, which — if successful — could lead either to public censure, a fine, or in the worst case scenario a prohibition order effectively barring the relevant individual from any future work within the UK financial services sector. Accordingly, insofar as the directors of UK banking and financial services companies are concerned at least, the FSA/FCA duty of care essentially replicates the corresponding generic corporate law duty of care, ${ }^{15}$ albeit with the lever of a

\footnotetext{
${ }^{11}$ Loughrey (2012b), p 13; 'Northern Rock drops legal claim against ex-directors', Independent, 14 October 2008.

12 See FSA (2011), p 354.

13 On these recorded factors, see FSA (2011), Part 1.

14 FCA Handbook, APER 2.1A.3, Statement of Principle 2.

15 In this regard, section 174 of the UK Companies Act 2006 requires that a director of a company exercises reasonable care, skill and diligence: that is to say, both: (a) the care, skill and diligence that would be exercised by a reasonably diligent person with the general knowledge, skill and experience that may reasonably be expected of someone carrying out the functions carried out by the director in relation to the company (the objective dimension of the duty); and (b) the general knowledge, skill and experience that the director actually has (the subjective dimension).
} 
public rather than private enforcement mechanism. The substantive considerations at play within each context are, however, fundamentally similar.

To anyone accustomed to the basic tenets of Anglo-American jurisprudence on directorial negligence issues, the FSA's eventual findings on this matter in the RBS case make for familiar reading. Indeed, on the basis of its Enforcement Division's investigation into the case, the FSA concluded in December 2011 that 'RBS made a series of bad decisions in the years immediately before the financial crisis, most significantly the acquisition of ABN AMRO and the decision to aggressively expand its investment banking business'. ${ }^{16}$ Notwithstanding, the FSA took the view that 'a number of decisions, which ultimately resulted in significant losses, were taken in 2006 and 2007 before the full extent of the financial crisis became apparent [...] based on assumptions and views that were shared by a significant number of other firms and market commentators'. ${ }^{17}$ Moreover, the FSA noted that, '[w]hile governance, systems and controls and decision-making [in RBS] may have fallen well short of best practice, and below the practices of a number of peer firms, the decisions taken and systems in place were not outside the bounds of reasonableness given all the circumstances at the time'. ${ }^{18}$ Accordingly, in the Authority's view, it would 'raise serious issues of unfairness' were its Enforcement Division to 'seek to apply standards of conduct retrospectively' in such cases, at least without being sensitive to 'the information available at the time'. ${ }^{19}$

On the above basis, the FSA therefore determined that public-disciplinary proceedings against RBS's former directors and other key officers on negligence grounds were not merited; a decision which, although not strictly concerned with the corporate law duty of care per se, nevertheless 'throws into doubt the utility of the duty of care as an accountability mechanism'. ${ }^{20}$ Meanwhile, in a similar vein, UK Financial Investments - the state-owned holding company charged with taking official stewardship of the government's majority stake in RBS and other British banks that were nationalised post-crisis-has steadfastly refrained from using its position to effect the initiation of any corporate law proceedings against RBS's former directors on general duty of care grounds.

In this regard, it is noteworthy that section 36 of the Financial Services (Banking Reform) Act 2013 has since introduced (into the UK) the new criminal offence of reckless misconduct in the management of a bank. Prima facie at least, this might be regarded as compensating for the limitations of the corporate law duty of care as a restrospective director accountability mechanism, at least insofar as banking and other financial services companies are concerned (particularly as it carries the threat of a potential custodial sentence for offenders). However, criminal liability for this offence is expressly dependent on proof of 'recklessness'-that is, managerial conduct falling far below reasonable standards in the circumstances. This will expectedly be applicable only to the most manifest or egregious instances of

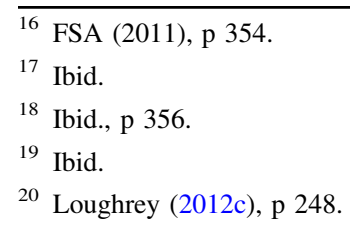


mismanagement prefacing a future banking failure. For the reasons already documented above, had such a provision existed prior to the 2007-2008 financial crisis the conduct of RBS's management in the run up to the bank's 2008 collapse would likely not have been deemed sufficiently outlandish to constitute 'recklessness' within the meaning of this Act. The introduction of this offence is therefore, in itself, unlikely to lead to any significantly greater likelihood of public enforcement action on directorial negligence grounds in future. Moreover, there is no corresponding provision applicable outside of the specific financial sector context. ${ }^{21}$

\section{The Futility of the Director's Duty of Care in the United States after the Crisis}

Similarly to the RBS/FSA scenario documented above, in the Citigroup Shareholder Derivative Litigation $^{22}$ in the United States, a corporate law duty of care action brought by shareholders against the directors of the failed bank during the years leading up to the financial crisis was in 2009 thrown out by the Delaware Chancery Court on standard business judgment rule grounds. The shareholder plaintiffs' essential complaint in this case was that Citigroup's directors at the relevant time-including its former CEO Charles (Chuck) Prince-entirely failed to monitor and manage the significant risks to which the company was exposed in the credit and sub-prime mortgage markets, in connection with its extensive dealings in mortgage-backed 'CDO' (i.e. collateralised debt obligation) securities. Plaintiffs further alleged that the defendant directors, apparently fixated on maximising their company's short-term profitability, had consciously ignored a number of highly conspicuous public warnings (or 'red flags') that prefaced the coming downturn in those markets. According to plaintiffs, such purported 'red flags' included the steady decline of the US housing market in the years immediately preceding the crisis, the sharp increase in residential mortgage defaults during this period, and also the substantial losses previously reported by other financial services conglomerates undertaking similar activities to Citigroup. ${ }^{23}$

By crafting their allegations against Citigroup's former directors in terms of both: (1) a complete abrogation of their collective risk oversight responsibilities and also (2) a conscious neglect of the clear warning signals to which they were (or, at least, should have been) alerted, plaintiffs were able to present their case as a so-called 'Caremark claim' premised on the defendants' purportedly deliberate (that is to say, bad faith) disregard of duty. The practical significance of plaintiffs designing their argument in this way derives from that fact that Delaware-incorporated firms are expressly permitted by statute to include exculpation clauses in their certificates of incorporation. These provisions have the effect of immunising directors from any prospective personal monetary liability flowing from future breach of their general corporate law duties. ${ }^{24}$ Significantly, though, whilst exculpation clauses may

\footnotetext{
21 On this provision generally, see Lowry et al. (2015), pp 79-80.

22 See In re Citigroup, Inc. Shareholder Derivative Litigation 964 A 2d 106 (Del Ch 2009).

23 Ibid., p 111.

24 See Delaware General Corporation Law, § 102(b)(7); Moore (2013), pp 103-105.
} 
legitimately take effect with respect to directors' liability (where it exists at all) for 'straight' gross negligence stemming from particular decisions, acts or omissions; such provisions are expressly precluded by statute from applying (inter alia) to any breach of the director's duty of loyalty, or for acts or omissions not in good faith or which involve intentional misconduct or a knowing violation of law. ${ }^{25}$

A highly noteworthy offshoot of this - as exemplified pertinently in Citigroupis that shareholder plaintiffs' attorneys in Delaware have developed a somewhat creative knack for seeking to side-step exculpation clauses that would otherwise preclude derivative litigation against allegedly negligent directors. This has been achieved-admittedly with differing degrees of success-by effectively 'repackaging' directorial negligence allegations in the form of duty of loyalty, in addition to duty of care, based claims (known as Caremark claims). However, from a doctrinal point of view this is a highly difficult feat, which is only possible in a narrow and heavily restricted range of instances: specifically, in cases where sustained or systematic board internal control or oversight failure is alleged.

In the landmark 1996 Caremark $^{26}$ case itself, the Delaware Chancery Court ${ }^{27}$ accepted the proposition that, in limited instances, a high-level oversight failure could be regarded as indicative not just of gross negligence but also of a certain element of disloyalty on the board's part, thereby deactivating defendant directors' exculpatory protection in respect of any consequent money damages liability. Chancellor Allen's opinion in Caremark was highly significant in setting a clear doctrinal signpost for the construction of future director negligence actions in Delaware. In particular, Chancellor Allen accepted that, whereas: on the one hand, the 'mere' failure by a board to act on a properly informed basis was in general indicative of (exculpable) gross negligence; on the other hand, where a board completely fails to ensure that a proper intra-firm monitoring or oversight system is in place, the relevant directors might potentially be regarded not just as breaching their duty of care, but-moreover-as consciously or intentionally disregarding it, thereby throwing up the requisite element of bad faith that is necessary to nudge their conduct into the category of non-exculpable breaches of duty. However, Chancellor Allen stressed that the (soon-to-be-called) 'Caremark doctrine' could not be invoked lightly, but rather that 'only a sustained or systematic failure of the board to exercise oversight—such as an utter failure to attempt to assure a reasonable information and reporting system exists-will establish the lack of good faith that is a necessary condition to liability'. ${ }^{28}$

Accordingly, plaintiffs' Caremark claim in Citigroup was designed to surpass the exculpatory protection that the defendant directors would otherwise have been entitled to. Notwithstanding the conceptual ingenuity of their pleadings, though, the

\footnotetext{
25 Ibid.

${ }^{26}$ See In re Caremark International 698 A 2d 959 (Del Ch 1996).

${ }^{27}$ As subsequently reaffirmed by the (higher) Delaware Supreme Court in the 2006 case of Stone v. Ritter 911 A 2d 362 (Del 2006).

${ }^{28}$ See n. 26 above, p 971. In the UK, by contrast, there is no need for shareholder claimants to bring directorial negligence allegations into duty of loyalty (as opposed to duty of care) territory, because exculpation clauses have for a long time been (and, indeed, remain today) rendered invalid by statute on public policy grounds. See Companies Act 2006, s. 232(1).
} 
allegations in question were deemed insufficient to withstand defendants' pre-trial motion to dismiss, with the outcome that the case effectively collapsed. Indeed, in Chancellor Chandler's view, plaintiffs' allegation in Citigroup-although phrased in terms of a Caremark claim-was in substance nothing more than an argument 'that the director defendants should be personally liable to the Company because they failed to fully recognize the risk posed by subprime securities' ${ }^{29}$ According to Chancellor Chandler:

[w] hen one looks past the lofty allegations of duties of oversight and red flags used to dress up these claims, what is left appears to be plaintiff shareholders attempting to hold the director defendants personally liable for making (or allowing to be made) business decisions that, in hindsight, turned out poorly for the Company. ${ }^{30}$

Moreover, Chancellor Chandler believed that the so-called 'red flags' or warning signals listed in plaintiffs' complaint, far from suggesting 'that the directors consciously disregarded their duties or otherwise acted in bad faith', were 'at most [...] evidence that the directors made bad business decisions' ${ }^{31}$ Accordingly, the Court took the view that a convincing case for disapplying the protection conventionally afforded to directors' risky decisions by the business judgment rule had not been made out. Nor did the Court regard the plaintiffs' allegations in Citigroup as even constituting a proper Caremark claim, given that they principally concerned the board's alleged faulty monitoring of inherent business risks to which the ordinary cloak of judicial business judgment protection applies. ${ }^{32}$ Indeed, Chancellor Chandler opined that it is in exactly these type of scenario that the protection of the business judgment presumption should be upheld. ${ }^{33}$

As the Court further highlighted, the essentially subjective and entrepreneurial nature of the alleged risk factors at play in Citigroup was in notable contrast to the risks involved in the earlier Caremark case itself, which essentially concerned directors' failure to identify legal compliance risks arising in the US commercial health care sector due to their allegedly faulty monitoring of employee misconduct. ${ }^{34}$ In this regard, the facts of the Citigroup case were also deemed to be distinguishable from those of the roughly contemporaneous Delaware post-crisis case of AIG Group. $^{35}$ In $A I G,{ }^{36}$ shareholder plaintiffs had-earlier in 2009contrarily succeeded before the same Court with a Caremark claim against senior

\footnotetext{
${ }^{29}$ Citigroup Shareholder Derivative Litigation, n. 22 above, p 124.

30 Ibid. (emphasis added).

31 Ibid., p 128.

32 Ibid., p 123. For a similar Delaware judicial opinion in response to a post-crisis Caremark claim concerning a banking company board's internal control practices, see Vice Chancellor Glasscock's ruling in In Re The Goldman Sachs Group, Inc. Shareholder Litigation 2011 WL 4826104 (Del Ch 2011).

33 Ibid., p 131.

34 Ibid., pp 123-124.

35 Ibid., p 130.

36 See In re American International Group, Inc. Consolidated Derivative Litigation 965 A 2d 763 (Del Ch 2009).
} 
officers of a competitor financial services company, on the basis of the defendants' allegedly conscious tolerance and facilitation of a widespread system of executive accounting fraud within the firm (which was notably described by then-ViceChancellor Strine as tantamount to a 'criminal organization' ${ }^{37}$ ).

In summary, then, it can be said that both the RBS and Citigroup cases discussed above, despite their very different jurisdictional and procedural settings, highlight a common fundamental issue that goes to the very heart of the director's duty of care as an effective corporate governance mechanism. That is, where a public company internal control failure derives at root from the adverse materialisation of inherently subjective entrepreneurial risks, the full consequences of which were impossible to predict or discern in advance, it is almost certain that the conduct of the directors concerned will be deemed exempt from the spotlight of retrospective judicial evaluation. ${ }^{38}$

So much would appear to be clear in the realm of corporate law anyway. However, as will be shown below, on a corresponding analysis of the distinct field of securities law, a rather different picture emerges with respect to the ambit of liability protection afforded to senior corporate officers in connection with alleged public company internal control failings.

\section{Securities Litigation as an Effective Substitute for Duty of Care Actions in Risk Oversight Failure Scenarios}

For understandable reasons the Citigroup decision has proved highly uncontroversial, and many commentators have been quick to criticise Chancellor Chandler for purportedly constraining the scope of Caremark claims in Delaware to an excessive degree. ${ }^{39}$ However, any sting that this negative ruling imposed on the plaintiff shareholders in this case was quickly counteracted by the positive outcome of a contemporaneous federal securities law action brought by investors against the bank's former senior officers, remarkably on account of more or less the same catalogue of alleged managerial misconduct.

By way of background, at roughly the same time as filing the abovementioned derivative action in the Delaware (State) Chancery Court alleging breach of duty by Citigroup's directors, the investor plaintiffs filed a further federal complaint in the United States District Court for the Southern District of New York. ${ }^{40}$ In the latter action, plaintiffs alleged that a number of Citigroup's senior officers (notably including the company's former CEO, Chuck Prince) had committed federal securities fraud by failing to disclose to investors the true extent of Citigroup's exposure to risks in connection with the sub-prime mortgage market, and also for overstating the value of the company's mortgage-backed asset portfolio prior to the crisis (that is, at least until the company issued a final corrective disclosure on those

\footnotetext{
37 Ibid., p 799.

38 For a theoretical rationalisation of this general judicial position, see Bainbridge (2004).

39 See, e.g. Bainbridge (2009); Gevurtz (2010); Miller (2010); Hill and McDonnell (2013).

40 See In re Citigroup, Inc. Securities Litigation, 09 MD 2070 (SHS) (Nov 9, 2010), 753 F.Supp.2d 206 (S.D.N.Y. 2010).
} 
matters in April 2008). ${ }^{41}$ The specific pleadings and ruling in this case will be discussed in the following section. However, it is necessary to digress for a moment here to provide some general background to the relationship between corporate and securities law actions in the United States, at least insofar as cases concerning board oversight failure are concerned.

At first sight, the notion of plaintiffs filing a federal securities fraud suit in the alternative to a corporate law duty of care complaint might appear somewhat perplexing. Given that securities fraud litigation tends in general to focus on alleged informational or disclosure lapses by corporate officers, it is perhaps not automatically clear what relevance such actions have to the seemingly distinct context of corporate mismanagement or oversight failure, which is the traditional domain of corporate law derivative litigation against directors. To explain, the essential point here is that serious high-level internal control failings in public companies are typically accompanied by a corresponding lapse in informational flows to the firm's relevant primary or secondary capital markets. This is because, self-evidently, key corporate risk exposures can only be publicly disclosed to the market where they are known and thus recognised as such by management. However, in cases of adverse eventualities which were not even anticipated or recognised as discernible 'risks' as such by management at the relevant time, ${ }^{42}$ both: (1) a company's internal controls over risk, and (2) its market-informational flows with respect to key corporate risk exposures, will be commonly deficient.

Therefore in instances of faulty management or board risk recognition, (substantive) internal control failure and (procedural) market-informational failure in effect conflate into one another, insofar as the same basic issue-that is, management's outright failure to identify (or, at least, publicly acknowledge its identification of) key corporate risk exposures-will be the common root cause of both the internal control and misinformation lapses. This potentially opens the door for harmed investors to the alternative of a securities law action centred on alleged managerial misinformation in connection with severe or systemic internal control lapse, additionally or alternatively to a corporate law (derivative) action premised on alleged board oversight failure per $\mathrm{se}^{43}$

Admittedly, the idea of applying securities law to notionally 'internal' business affairs such as directors' responsibilities has for a long time provoked significant concern amongst commentators. ${ }^{44}$ In the United States, securities law (that is, the laws and ancillary rules concerning the regulation of public securities markets) is traditionally seen as the rightful domain of the federal government, in particular the Securities and Exchange Commission (which exercises delegated rulemaking authority in this field under the Securities Exchange Act of 1934) and federal district courts (who are charged with adjudicating in the first instance on disputes concerning the application of federal statutes and ancillary SEC Rules). On the other

\footnotetext{
41 'Citigroup subprime securities class action upheld but limited after motion to dismiss', Mayer-Brown Legal Update, 8 December 2010.

42 On this, see Moore (2010), p 295.

43 Bratton and Wachter (2011), p 126.

44 See, e.g. Fleischer (1965), pp 1153-1154; Romano (2005); Bainbridge (2012), ch. 1.
} 
hand, corporate law (understood as the rules and principles governing the internal affairs of incorporated organisations) is regarded as the exclusive preserve of the individual states, from which federal lawmakers should accordingly abstain. ${ }^{45}$ Moreover, it is generally believed that state legislatures and courts in the US are driven by pressure from the market for incorporations to provide legal provisions that are generally amenable to the controllers of incorporating (or reincorporating) business firms, including robust liability protection for directors in the form of the business judgment rule. ${ }^{46}$ On the other hand, the federal rule-makers and courts which operate in the securities law domain do not operate under these same constraints. It follows that they arguably have a stronger predilection than their state-level counterparts to seek to uphold high standards of investor protection, even where this has the effect of increasing corporate officers' concomitant liability risk. $^{47}$

Accordingly, if investor plaintiffs are readily permitted to side-step the application of the business judgment rule in board oversight failure cases by simple recourse to a misinformation-based action in the federal courts, the whole premise of this customary partition between state and federal law will be undermined. Indeed, in recognition of this concern, US federal courts have steadfastly refused to entertain the proposition that federal securities fraud claims can be brought to 'remedy' breaches of directors' duties under state law per se. ${ }^{48}$ However, this does not necessarily preclude the abovementioned Citigroup scenario of formally separate state and federal actions being brought by investor plaintiffs on account of fundamentally the same set of alleged facts.

In advancing what is arguably the most systematic academic rationalisation of this issue to date, Thompson and Sale have gone so far as to claim that, in the United States at least, securities fraud class actions 'have become the most visible means of regulating corporate governance'. ${ }^{49}$ Accordingly, they posit that such actions 'are working to fill the hole [...] brought about by the lack of liability for, and concomitant inability to sustain, [corporate law] suits for breaches of the fiduciary duty of care'. ${ }^{50}$ Whilst Thompson and Sale acknowledge that securities fraud actions inevitably require 'a disclosure hook', they argue that such actions are in substance and effect 'usually claims against officers for breaches of the duty of care or monitoring during the day-to-day running of the corporation'. 51

\footnotetext{
45 On the artificiality of the corporate v. securities law distinction in US academic and policy-making discourse, see Moore (2017).

46 On this phenomenon generally, see Bebchuk (1992); Romano (1993).

47 On the notion of 'investor primacy' as a centrifugal principle of US securities law (in distinction from the doctrine of director primacy that is central to Delaware corporate law), see Velikonja (2015).

48 The landmark decision in this regard was the Supreme Court's ruling in the 1977 case of Santa Fe Industries v. Green 430 US 462. In this case, the Court held that the presence of some form of manipulation or deception was a necessary component of securities fraud under SEC Rule 10b-5 (on which, see Sect. 5 below), thereby precluding the application of this provision to standard breaches by directors' of their state law fiduciary duties. On this, see Langevoort (2001); Wu (2006), p 252.

49 Thompson and Sale (2003), p 860.

50 Ibid., p 905.

51 Ibid., p 910.
} 
Amongst the relative practical advantages of securities law misinformation claims for investors is the fact that such actions-as essentially personal claimsprovide a direct remedy for affected investors. They thus compare highly favourably from an investor perspective to corporate law derivative claims, which contrarily entail the syphoning off of any resulting monetary damages to the formally suing corporate entity itself. ${ }^{52}$ Additionally there is that fact that, from an evidentiary point of view, 'disclosure questions [...] can be more easily handled under the current legal regime than questions alleging a duty to supervise and monitor' ${ }^{53}$

Likewise from an evidentiary perspective, there is the generally lesser difficulty for plaintiffs/claimants in securities law misinformation actions-in comparison to corporate law duty of care claims - of establishing loss causation. In securities law misinformation claims the plaintiff/claimant's loss is essentially measured by the difference between: on the one hand, the (inflated) purchase price of their shares; and, on the other, the (lower) 'reset' value of their shares after the true set of facts or circumstances is disclosed (for instance, in management's eventual corrective earnings disclosure), with the misleading statement or omission in question constituting the single 'trigger point' as such for causation purposes. ${ }^{54}$ However, in corporate law duty of care cases, the corresponding trigger point for causation purposes - that is, the board's allegedly negligent monitoring or oversight failureis considerably more difficult to delineate as a distinct operating cause of the plaintiff/claimant's eventual losses, particularly in highly complex scenarios (such as the abovementioned Citigroup and $R B S$ cases) where there are a number of overlapping possible operating causes at play simultaneously. ${ }^{55}$

This is not to say that securities fraud actions are by any means a panacea for investors, whether in board oversight failure scenarios or otherwise. Rather, their effectiveness as a redress mechanism is undermined by a number of significant and well-documented factors. Chief amongst these is the so-called 'circularity problem', whereby any damages award or settlement arising from such an action is almost always funded by the relevant company itself (whether directly as a wealthier codefendant to the suit, or indirectly via indemnification of a defendant officer). This means that-in effect - the company's current body of shareholders at the time of judgment/settlement compensates the previous group of shareholders who were harmed by the managerial misdemeanour in question. ${ }^{56}$ However, in a welldiversified securities marketplace both groups will almost certainly overlap to a large extent, such that receipts versus payments of damages 'balance over time'. 57

\footnotetext{
52 Ibid., p 861.

53 Ibid., p 906. Thompson and Sale explain (at p 864) that '[corporate law directors'] duty litigation, with its amorphous focus on directors' failure to monitor officers and other parts of the enterprise, is at a systematic disadvantage relative to [securities] law which, in a more focused way, seeks to explore what officers need to do to meet their corporate disclosure obligations'. Whilst the authors were referring specifically to the applicable US legal regime in this regard, their observation would appear to be comparably valid in a UK context.

54 Langevoort (2009), p 180.

55 On this issue generally, see Thompson and Sale (2003), pp 907-908.

56 On this, see Coffee (2006); Fisch (2009).

57 Bratton and Wachter (2011), p 76.
} 
The ultimate distributive outcome-according to two eminent critics of such actions - is 'a wash [...] that ripens into a net loss once we account for attorneys' fees, liability insurance premiums, and other costs'. 58

Notwithstanding these concerns, it should be borne in mind that even where securities fraud actions do not result in direct monetary consequences for defendant directors, it cannot be said that either the deterrent or vindicatory value of such actions is thereby negated. On the contrary, the reputational damage that may ensue from a director's publicised involvement in a costly unsuccessful lawsuit, along with the indirect disciplinary effect of any consequent devaluation of that individual's human capital, should not be underestimated. ${ }^{59}$ Nor should the adverse personal impact to directors of the 'substantial nuisance' 60 that being a party to complex litigation inevitably entails, irrespective of who ends up bearing the immediate pecuniary costs thereof.

Moreover, recent theoretical analyses of the notion of board accountability in corporate governance have emphasised the importance of directors being held 'answerable' - in the sense of being required to 'explain and justify their conduct against a set of externally set values and standards, ${ }^{61}$ —as a precondition to sustaining the legitimacy of their decision-making authority within the firm. ${ }^{62}$ To the extent that securities law misinformation claims relating to alleged board oversight failure can be said to provide this function (albeit in an imperfect and indirect way), it follows that the limited capacity of such actions to impose direct pecuniary costs on defendant officers need not be fatal to their continuing relevance as a meaningful accountability mechanism.

Accordingly, in the sections that follow, three of the most pertinent examples of recent Anglo-American litigation in this regard are analysed in turn.

\section{The Citigroup (US) Securities Litigation}

As discussed in Sect. 3 above, in the 2009 corporate law litigation that arose out of the collapse of the US financial services conglomerate Citigroup, a shareholder derivative suit brought against the company's former directors to recover losses flowing from its 2007-2008 share price collapse was dismissed by the Delaware Chancery Court. This was essentially on the basis that, in the Court's opinion, the plaintiffs had not demonstrated a sufficiently strong case to justify disapplication of the business judgment protection to which the defendants were ordinarily entitled in making (what turned out to be disastrous) risky business decisions concerning the firm's exposure to the credit and sub-prime mortgage markets pre-2008. ${ }^{63}$ However, against this background, the corresponding fate of the contemporaneous federal securities law action brought by investors against the bank's former senior

\footnotetext{
58 Ibid.

59 Black et al. (2006a), p 1140; Black et al. (2006b), p 16.

60 Black et al. (2006a), p 1140.

61 Keay and Loughrey (2015), p 267.

62 See Moore (2015).

63 See nn. 29-38 above and accompanying text.
} 
officers-on account of more or less the same catalogue of alleged managerial misconduct-makes for extremely interesting reading.

By way of background, at roughly the same time as filing the abovementioned derivative action in the Delaware (State) Chancery Court alleging breach of duty by Citigroup's directors, the investor plaintiffs filed a further federal complaint in the United States District Court for the Southern District of New York. ${ }^{64}$ In the latter action, plaintiffs alleged that a number of Citigroup's senior officers (notably including the company's former CEO, Chuck Prince) had violated federal securities law by failing to disclose to investors the true extent of Citigroup's exposure to risks in connection with the sub-prime mortgage market, and also for overstating the value of the company's mortgage-backed asset portfolio prior to the crisis (that is, at least until the company issued a final corrective disclosure on those matters in April 2008). ${ }^{65}$

Specifically, plaintiffs in this case alleged that the defendant officers had breached SEC Rule 10b-5, which provides (inter alia) that it shall be unlawful for any person, directly or indirectly either: (1) to make any untrue statement of a material fact (the prohibition on misleading managerial statements), or (2) to omit to state a material fact necessary in order to make the statements made, in the light of the circumstances under which they were made, not misleading (the prohibition on misleading managerial omissions) ${ }^{66}$ Essentially, the investors' case was that Citigroup's management had, via their alleged disclosure lapses, in effect overinflated market demand for the company's shares during the period immediately leading up to the crisis. On this basis, the relevant investor plaintiff group sought overall damages of $\$ 6.3$ billion, which was equivalent to the losses-in the form of reduced equity values - that they suffered consequent upon the subsequent market 'resetting' that took place during the financial crisis. ${ }^{67}$

Ultimately the plaintiffs succeeded in preliminarily inferring Rule 10b-5 securities fraud liability on the part of seven senior Citigroup officers at the relevant time (including Prince). This was sufficient to enable the claims against these individuals to proceed to trial and, in turn, compel a $\$ 590$ million pre-trial settlement of plaintiffs' action in August 2012. ${ }^{68}$ It is, at first sight anyway, somewhat perplexing that the Delaware (corporate law) and federal (securities law) courts seemed to take markedly different positions from one another in those two cases. In particular, the respective benches-in the context of ruling on preliminary strike-out motions brought by defendants-drew markedly different inferences from one another on the perceived (un)reasonableness of the relevant officers' conduct, when each confronted with what was essentially the same basic fact pattern.

\footnotetext{
${ }^{64}$ See In re Citigroup, Inc. Securities Litigation, 09 MD 2070 (SHS) (Nov 9, 2010), 753 F.Supp.2d 206 (S.D.N.Y. 2010).

65 'Citigroup subprime securities class action upheld but limited after motion to dismiss', Mayer-Brown Legal Update, 8 December 2010.

66 See n. 63 above, pp 20-22.

67 'Judge approves Citigroup \$590 million settlement', Reuters, 1 August 2013.

68 See In Re Citigroup, Inc. Securities Litigation, 09 MD 2070 (SHS) (Jan 29, 2013), pp 3, 18-23.
} 
The principal question facing the federal District Court in the Citigroup Securities Litigation was whether there were sufficiently particularised allegations (absent actual proof itself) on which the court could 'draw the reasonable inference that the defendant[s] is liable for the misconduct alleged', with 'reasonable' for this purpose defined as somewhere on the scale between 'probability' and mere 'possibility'. ${ }^{69}$ In attempting to persuade the Court otherwise, the defendants argued (inter alia) that no such inference could reasonably be drawn by the Court given the lack of any indication from the pleadings that they acted with 'scienter': that is to say, with fraudulent intent or at least knowledge of their own wrongdoing.

It is a notable feature of US securities fraud litigation that, even in situations (like the case at hand) where a clear inference of actual fraudulent intent by defendants cannot be made out, it is still possible for plaintiffs to infer the requisite element of scienter on the defendants' part by identifying circumstances which suggest either that the defendants consciously or intentionally neglected the company's disclosure obligations, or-alternatively-that they acted 'recklessly' in this regard. ${ }^{70}$ For this purpose, 'recklessness' is defined as 'conduct which is highly unreasonable and which represents an extreme departure from the standards of ordinary care to the extent that the danger was known to the defendant or so obvious to the defendant that the defendant must have been aware of it'. ${ }^{71}$

Note that, in the corresponding Delaware corporate law action discussed above, the state Court took the view that no claim of consciously or intentionally unlawful behaviour could be made out by plaintiffs, given the inherently subjective and 'business' nature of the risk factors that the defendant directors supposedly failed to acknowledge prior to the company's collapse. ${ }^{72}$ From this perspective, it would thus appear-prima facie at least-an extremely difficult task to establish (for securities fraud liability purposes) any clear inference that Citigroup's management had knowingly, consciously or at least recklessly failed to disclose the true extent of the company's risks, or the true value of its mortgage-linked asset portfolio, given the considerable degree of uncertainty and subjectivity apparently involved in making such determinations on an ex ante basis (at least if the Delaware Court is to be believed).

However the federal Court, in evaluating the defendant officers' behaviour with respect to their securities law risk disclosure (as opposed to corporate law risk oversight) responsibilities for evidence of knowing misconduct, opted to pick up on a very different factual theme from the Delaware Court, which was the defendants' apparent 'incongruity between word and deed' ${ }^{73}$ That is to say, in the federal Court's view, the defendants had simultaneously: (1) sought to present an external 'picture' to the market to the effect that the company (and, in particular, its

\footnotetext{
69 Ibid., p 20 (emphasis added).

70 On this, see Pan (2011), p 235.

71 See n. 68 above, p 22, quoting Honeyman v. Hoyt (In Re Carter-Wallace, Inc. Secs. Ltig.) 220 F.3d 36 (2d Cir. 2000), p 39 (emphasis added).

72 See nn. 29-33 above and accompanying text.

73 See n. 68 above, p 27.
} 
extensive CDO securities holdings) was generally insulated from exposure to turbulence in mortgage and credit markets; whilst (2) internally undertaking a series of activities (in particular between February 2007 and October 2007) which on the whole suggested that the company-in management's view-was anything but insulated from such risks. Such apparently inconsistent internal firm activities included purchasing credit default protection in respect of the purportedly 'safe' elements of its CDO holdings, setting up a special purpose entity to assume some of the credit risks arising from those holdings, changing the prospectuses for its CDO securities to reflect their perceived higher risk exposure, and also holding daily management meetings on the issue of the firm's CDO risk exposures. ${ }^{74}$

Plaintiffs alleged that none of the above issues had been mentioned in any of Citigroup's public disclosures to the market, at least prior to management's April 2008 corrective disclosure. In the federal Court's view, this clear behavioural inconsistency of Citigroup's management was indicative of an intentional-or, at least, conscious-effort to mislead the company's investors, thus establishing the requisite inference of scienter on the defendant officers' part. ${ }^{75}$ In notable contrast, the Delaware Court in its earlier judgment on the matter had firmly rejected the relevance of the defendant directors' alleged knowledge of any current or potential future deterioration in the sub-prime mortgage market, at least to the separate (corporate law) question of whether they had consciously disregarded their risk management or oversight responsibilities. ${ }^{76}$

\section{The RBS (US) Securities Litigation}

However, not all securities litigation in the United States relating to alleged internal control failings in banks before and during the financial crisis has proved successful (at least from the suing investors' perspective). Indeed, in this regard, the RBS Securities Litigation ${ }^{77}$ before the same federal Court stands out as a useful counter-example. In particular, it demonstrates that the federal District Court, whilst in general more willing than its Delaware counterpart to infer wrongdoing on the part of those officers responsible for alleged oversight lapses, is still likewise sensitive to the risk of exercising hindsight bias when making such determinations.

There were two core substantive components of this US-style consolidated class action, which merit particular attention here. The first aspect of the US RBS litigation was a federal securities law claim filed in 2009 against RBS and its former management, alleging breach of SEC Rule 10b-5. This action was initially brought in 2009 by US-based investors who had purchased RBS shares on the UK market, and who subsequently incurred significant losses when RBS's shares lost more than $65 \%$ of their value following the company's reporting of a $\$ 41.3$ billion loss in

\footnotetext{
74 Ibid.

75 Ibid.

76 See n. 22 above, p 128.

77 See n. 2 above.
} 
2008, prior to its compelled nationalisation. ${ }^{78}$ The key factual issues alluded to were very similar to those highlighted by the FSA in its abovementioned report into the bank's failure. Essentially, plaintiffs argued that the company and its management had breached Rule 10b-5 by making a series of false and misleading statements in public SEC filings with respect (inter alia) to the extent of RBS's exposure to subprime mortgage-related risks, the adequacy of its capital coverage following the ABN AMRO takeover, and also the goodwill recorded on its balance sheet in connection with this acquisition. ${ }^{79}$

The SEC filings in question related to certain American Depositary Receipt securities that RBS had listed in the United States, but notably not to its primary equity securities which were listed in London and therefore outside of the SEC's regulatory jurisdiction. Notwithstanding this fact, the plaintiffs contended that since RBS had at least some of its securities listed in the US, and also as the plaintiffs were US residents who purchased their shares in the company whilst in the United States, there was consequently a sufficient territorial connection to render RBS subject to the purview of US federal securities law. However, the federal District Court-following the then-recent decision of the US Supreme Court in Morrison $v$. $N A B^{80}$ — disagreed, holding that US securities law will only apply to a defendant issuer where the shares held by plaintiffs are themselves listed on a US exchange, or else purchased or sold in the United States (with neither of these conditions being satisfied in the case at hand). ${ }^{81}$ Accordingly, the claim was dismissed on jurisdictional grounds, leaving the question as to whether RBS and its management would have been held liable under SEC Rule 10b-5 (in the presence of a sufficient US territorial connection) unanswered.

The second notable component of the RBS Securities Litigation involved investors who purchased US-listed RBS dollar preference shares issued over the course of 2006 and 2007, who subsequently (in 2009) filed claims against the company and number of its senior officers and advisers under sections 11 and 12 of the federal Securities Act 1933. Notably, whereas Rule 10b-5 applies only to managerial communications that harm investors in the secondary market context (that is, with respect to transactions in existing, previously-issued securities), the above 1933 Act provisions establish a roughly analogous right of action for the primary market context, by prohibiting material misstatements and omissions in prospectuses and other listing particulars pertaining to newly issued securities. Essentially, they attribute direct civil liability to signatories, directors and underwriters of any issuing company whose registration statement and/or prospectus is consequently rendered untrue or misleading in any material respect(s).

As the securities pertaining to the relevant claims in this case actually were listed on a US exchange, the action was not liable to immediate strike-out on jurisdictional

\footnotetext{
78 'Federal securities claims dismissed in In re Royal Bank of Scotland based on Morrison', Mayer Brown Legal Update, 11 February 2011.

79 See In re Royal Bank of Scotland Group plc Securities Litigation, 09 Civ. 300 [2011] 002 IITRALR (Jan 11, 2011), 765 F.Supp.2d 327 (S.D.N.Y. 2011).

80 See Morrison v. National Australia Bank, 561 US 247 (2010).

81 See n. 79 above, para. 32 (Judge Deborah Batts).
} 
grounds at least. However, the relevant claims were nonetheless ultimately dismissed by the same federal District Court, albeit in this instance on the substantive ground that they failed to allege any actionable managerial misstatements or omissions under the relevant statutory provisions. ${ }^{82}$

In the case at hand, plaintiffs alleged that a number of senior officers and relevant associates of RBS had breached the above provisions by making misstatements and/ or omissions essentially similar to those cited in the abovementioned 10b-5 claim, albeit here in the context of issuances of new preference shares (as opposed to periodic market disclosures) in the years immediately prefacing the bank's 2008 collapse. Whilst the allegations put by plaintiffs were intuitively convincing, on closer inspection the federal Court found them to be significantly limited, and accordingly dismissed the claims in full.

In particular, the Court rejected plaintiffs' contention that defendants should have corrected a (arguably misleading) previous assertion in RBS's annual report to the effect that it was the company's policy to 'maintain a strong capital base'. In the Court's opinion, this statement should have been read as part of the broader context in which it was made: that is, as part of a discussion about RBS's compliance with then-existing capital adequacy requirements, where reference to the implications of the company's CDO holdings was not directly necessitated. ${ }^{83}$ The Court also disagreed with plaintiffs' claim that public assurances given by RBS's management between 2005 and 2007 about the strength of the company's overall credit quality were misleading. According to the Court, such statements were sustainable at the time of their making, given that the problematic CDO securities which were later to diminish the company's credit quality were during the relevant time period rated AAA by credit ratings agencies. ${ }^{84}$

Likewise, the Court dismissed plaintiffs' claim that RBS's management had misled investors by failing to disclose the consequences of the ABN AMRO acquisition for the group's overall level of exposure to sub-prime mortgage related risks. In this regard, the Court noted that RBS had previously 'made numerous disclosures as to the limited scope of its pre-acquisition due diligence review', and also to the possibility of financial and business harm stemming from ensuing 'unknown liabilities'. ${ }^{85}$ Finally, the Court deemed that allegedly misleading 'undue optimism' by RBS about the potential benefits of the ABN AMRO acquisition amounted to nothing more than 'inactionable puffery' on the part of its management, which offered no guarantees as to future outcomes and thus could not support any cause of action. ${ }^{86}$

Seemingly pivotal to the Court's decision to dismiss the claims against RBS's management and associates under the 1933 Act was its proposition that the (un)truthfulness of any statement for Securities Act purposes falls to be determined in accordance with the general state of knowledge at the time it was made, rather

\footnotetext{
82 See In re Royal Bank of Scotland Group plc Securities Litigation, 09 Civ. 300 (Sep 4, 2012).

83 Ibid., pp 15-16 (Judge Deborah Batts).

84 Ibid., p 18.

85 Ibid., pp 24-25.

86 Ibid., pp 26-27.
} 
than at the time of initiation of the relevant claim. ${ }^{87}$ On this basis, presiding Judge Deborah Batts concluded on the instant facts that '[p]laintiffs' reliance on hindsight alone is fatal to their claims' ${ }^{88}$ Interestingly for present purposes, this suggests that US federal (securities law) courts may be comparably uncomfortable to their Delaware (corporate law) counterparts about the perceived injustice of seeking to second-guess historical managerial conduct, albeit here in the specific context of determining what disclosures corporate officers and underwriters should have made to investors when promoting fresh public securities issuances. Therefore, whilst it would appear that investor plaintiffs in the United States are-all other things being equal-more likely to succeed in inferring conscious managerial impropriety in internal control failure cases by taking the securities law rather than corporate law route, the former path is still by no means a free pass for them in this respect.

\section{The RBS (UK) Rights Issue Litigation}

It was noted above that, in the United Kingdom, the (then) FSA's decision not to pursue (de facto corporate law) negligence proceedings against RBS's former directors on grounds of lax risk management was attributable to the Authority's belief that the relevant strategic decisions reached-whilst highly problematic in a number of respects-were ultimately not outside the bounds of reasonableness given the information available to decision-makers at the time. ${ }^{89}$

As regards the potential liability of RBS's former management on securities law grounds, though, the dismissal of the above US claims in 2011 was far from investors' final say on the matter. Rather, at the time of writing, RBS and certain members of its former senior management team remain subject to private enforcement proceedings in the United Kingdom in connection with a high profile and, ultimately, disastrous shareholder rights issue implemented shortly before the bank's 2008 implosion and subsequent public bailout. ${ }^{90}$

By way of background, on 30th April 2008, RBS published a prospectus for what would, at the time, become the largest rights issue in UK corporate history. RBS was seeking to raise $£ 12.3$ billion, and the rights issue price was 200 p per share. During the formal period of the rights issue, from 15th May 2008 to 6th June 2008, over 170 institutional investors consequently subscribed for significant amounts of new RBS shares, and many thousands of other (largely retail) shareholders made relatively small investments. ${ }^{91}$ It has since been alleged that, in its public communications at the relevant time, RBS's top executive directors made a series of misleading statements which its prospectus subsequently failed to correct or clarify. $^{92}$

\footnotetext{
87 Ibid., p 19.

88 Ibid., p 13.

${ }^{89}$ See nn. 16-20 above and accompanying text.

90 See RBS Rights Issue Litigation, n. 1 above.

91 Ibid., paras. 1-10 (Hildyard J).

92 Ibid., para. 19.
} 
In particular, it is claimed that 'the Directors made recklessly optimistic statements which gave a grossly misleading impression of the underlying strength of the bank'. ${ }^{93}$ Such alleged statements notably included a public assertion by RBS's then-CEO Fred Goodwin in February 2008 (2 months prior to announcement of the rights issue) that 'the positive view that we have of the $\mathrm{ABN}$ businesses has been confirmed', and that ' $[\mathrm{t}]$ here are no plans for any inorganic capital raising or anything of the sort'. ${ }^{94}$ This statement-coupled with the absence of any offsetting or clarifying proviso in RBS's subsequent prospectus-is said to have created an erroneous inference that the rights issue was for the purpose of merely improving the bank's existing capital ratios, and that the bank would have a sufficient level of capital to continue its ongoing operations.

Relatedly, RBS and its senior management at the time have been accused (inter alia) of failing to mention in the rights issue prospectus that the FSA had actually insisted on such a large-scale issue taking place, as an urgent means of rectifying the significant damaged inflicted on the bank's balance sheet by the ABN AMRO acquisition. Nor allegedly did the company or its management disclose-either prior to the rights issue or in the prospectus itself-that the bank had been compelled, on two separate occasions between February and April 2008, to draw on emergency funding from the US Federal Reserve to avert imminent liquidity crises. ${ }^{95}$

Further notable alleged omissions in RBS's right issue prospectus include nondisclosure of its capital ratios (in breach of regulatory requirements), and also failure to make appropriate write-downs in goodwill once the true nature and extent of ABN AMRO's exposure to subprime mortgage-related risks had become apparent to RBS's management. It is also claimed that, as a result of the above catalogue of misstatements and omissions, RBS and its senior management in effect created a 'false market' in order to raise the requisite $£ 12.3$ billion, as demonstrated by the significant deterioration in RBS's share price (by in excess of $95 \%$ of the rights issue price) that occurred following revelation of the true state of the company's financial affairs later in 2008, and its subsequent compelled nationalisation. ${ }^{96}$

Litigation based on the above alleged misconduct was initiated by five separate groups of claimants under the Financial Services and Markets Act (FSMA) 2000. ${ }^{97}$ Essentially, the relevant provisions of this $\mathrm{Act}^{98}$ attribute liability for negligent

\footnotetext{
93 See RBoS Shareholders Action Group, 'About Us' at http://www.rbosaction.org/about.cfm.

94 Ibid., 'The Case Against RBS and Named Directors'.

95 Ibid. Likewise, the concurrent litigation concerning the collapse of the British banking group Lloyds HBOS in 2009 pivots essentially on allegations by investor claimants (albeit on general private law, rather than specific securities law, grounds) to the effect that the then-directors of Lloyds misled the company's shareholders by failing to inform them of the true extent of HBOS' financial difficulties (including its compelled resort to significant emergency public funding) when advising on the merits of Lloyds' government-brokered acquisition of HBOS in January 2009. See Sharp v. Blank, n. 3 above; 'Lloyds shareholders launch $£ 350$ m HBOS lawsuit', The Telegraph, 22 July 2015.

96 RBoS Shareholders Action Group, n. 93 above.

97 See n. 1 above, paras. 13, 16.

98 These are section 90-and, relatedly, section 87A-of FSMA 2000. Although the wording of the former section prima facie relates to the content of an issuer's listing particulars (as opposed to that of its prospectus), s. 90(11) expressly provides that the section applies also in relation to prospectus content.
} 
prospectus misstatements or omissions to any persons who are deemed responsible for the information given in the prospectus, including the issuer's individual directors or executive officers at the time of its publication. ${ }^{99}$ For the purpose of determining the actionability of any alleged prospectus omission, the Act requires that an issuer's prospectus contains all such information as is necessary to enable investors to make an informed assessment of (inter alia) the assets and liabilities, financial position, profits and losses, and prospects of the issuer of the securities. ${ }^{100}$ This includes (inter alia) information relating to the essential characteristics of, and risks associated with, the issuer, including their assets, liabilities and financial positions. $^{101}$

Furthermore, if at any time after the issuer's prospectus is approved by the FSA/FCA but before the end of the rights issue period, there arises or is noted a significant new factor, material mistake or inaccuracy relating to the prospectus' content, the issuer must thereafter submit a supplementary prospectus to the FSA/FCA containing details of the relevant new factor, mistake or inaccuracy. ${ }^{102}$ For this purpose, 'significant' means significant for the purpose of making an informed assessment of the assets and liabilities, financial position, profits and losses, and prospects of the issuer. ${ }^{103}$

In the present litigation, claimants averred that-in making the above misstatements and omissions-RBS and/or its senior officers presented an untrue and/or misleading impression of the company's true state of financial affairs at the relevant time, which they subsequently failed to rectify. ${ }^{104}$ Four of the actions in question exclusively named RBS as the relevant 'person responsible' for the rights issue prospectus' content, whereas one of the actions ${ }^{105}$ additionally named four key former senior officers of RBS (notably including its former CEO, Fred Goodwin ${ }^{106}$ ) as 'persons responsible' in addition to the company itself. ${ }^{107}$

In February 2014, the English High Court (per Hildyard J) made a Group Litigation Order (GLO) with respect to the various individual actions in this regard, which have since been referred to under the common case name of Greenwood $v$. Goodwin. ${ }^{108}$ In particular, this has enabled the GLO Court (in effect, Hildyard J) to manage all claims with a view to achieving a single resolution of the common

\footnotetext{
99 This is consistent with Art. 6(2) of the EU Prospectus Directive (Directive 2003/71/EC), [2003] OJ L $345 / 64$.

100 FSMA 2000, s. 87A(2).

101 Ibid., s. 80(3).

102 Ibid., s. $87 \mathrm{G}$.

103 Ibid., s. 87G(4).

104 Ibid., s. 90(1).

105 Namely the RBoS Shareholders Action Group suit.

106 The three other named individual officers are RBS's former chairman Sir Tom McKillop, its former head of investment banking Johnny Cameron, and its former finance director Guy Whittaker.

107 Notably, a request in July 2015 to have the four additional individual defendants to the RBoS Shareholders Action Group claims (including Goodwin) excluded from the writ on grounds of perceived 'injustice' was swiftly dismissed by Hildyard $\mathrm{J}$ in the 7th Case Management Conference on the litigation. See 'RBS lawyers fail in attempt to distance themselves from Fred Goodwin as trial approaches', Herald Scotland, 2 August 2015.

108 See n. 1 above.
} 
issues, and also to require all claimants to agree to be bound by any future resolution of those issues. ${ }^{109}$ In this regard, Hildyard $\mathrm{J}$ has determined the common substantive issues in the case to be: (1) whether RBS made misleading disclosures in its prospectus ${ }^{110}$ and/or omitted necessary information, ${ }^{111}$ and whether a supplementary prospectus should subsequently have been issued ${ }^{112}$; (2) whether the claimants suffered loss and issues of causation; and (3) whether the defendants (or at least RBS itself) have a statutory defence available to the above allegations, most notably on the purported premise that any misstatement or omission in the prospectus was based on a reasonably held belief in the truthfulness or propriety thereof. ${ }^{113}$

The expected trial date for the case is March 2017. ${ }^{114}$ In view of the anticipated time frame, a final verdict on the case is unlikely to emerge until 2018 at the earliest. At the time of writing, RBS has recently agreed a settlement of the litigation with three of the five claimant groups, which together account for $77 \%$ of the overall claims by value. ${ }^{115}$ Notably, though, the RBoS Shareholders Action Group suit against both the bank and its former individual officers remains unsettled, as does the separate RBS Rights Issue Action Group's claim. ${ }^{116}$ Moreover, as things stand, it would appear that the chances of the former group in particular reaching a pretrial settlement of their action are highly uncertain, given its expressed commitment to ensuring that the individual defendants (i.e. Goodwin, McKillop, Cameron and Whittaker) are held answerable for their alleged misconduct before a court, coupled with the apparent insistence of RBS's representatives that any pre-trial settlement entail no admission of personal fault or liability on the part of any of those four individuals.

In the event that the case does ultimately proceed to trial, it is naturally difficult at the present time to speculate on the likely outcome. On the one hand, the failure of the abovementioned 2009 prospectus-based litigation in the United States against RBS's former directors and underwriters ${ }^{117}$ might be construed as an ominous warning sign for claimants in the present UK litigation, given the substantive similarities between the respective statutory provisions at issue in the two cases. ${ }^{118}$ On the other hand, it should be noted that the earlier RBS prospectus litigation in the United States concerned a series of dollar preference share issues carried out by the company in 2006 and 2007 when-arguably unlike at the time of its later (April

\footnotetext{
109 Ibid., para. 20(4).

110 Prohibited by FSMA 2000, s. 90(1).

111 As defined by FSMA 2000, s. 87A.

112 As required by FSMA 2000, s. 87G.

113 Under FSMA 2000, Schedule 10, para. 1(2). On all of these issues, see n. 1 above, para. 19.

114 'RBS litigation: judge takes defence team to task over "less than wholly satisfactory" disclosure process', Legal Business, 26 November 2015.

115 'RBS agrees multimillion-pound deal with shareholders', The Guardian, 5 December 2016.

116 'RBS faces lengthy legal battle after some investors reject $£ 800 \mathrm{~m}$ rights issue settlement', The Telegraph, 5 December 2016; 'RBS investors proceed with $£ 1.25$ bn claim over rights issue’, Financial Times, 27 October 2016.

117 On this, see Sect. 6 above.

118 Namely section 11 of the US federal Securities Act of 1933, and section 90 of (UK) FSMA 2000.
} 
2008) UK rights issue - the true nature and extent of the risks to which the company was exposed had not yet become apparent (even, it would seem, to RBS's management itself). Accordingly, the facts of the two cases cannot reasonably be analogised to one other.

Notwithstanding the final outcome of the UK rights issue litigation, though, the extent to which proceedings in this case have advanced so far, coupled with the complete lack of any private or public enforcement proceedings against RBS's former (pre-crisis) board on directorial negligence grounds, would tentatively indicate that securities law-rather than corporate law-is becoming the principal remedial avenue of choice for aggrieved investors today in respect of high-level public company internal control failings, in the United Kingdom as in the United States. Admittedly, there is cause for a certain degree of caution in making this prediction on the basis of the RBS example alone. Indeed, a noteworthy element of this case is the fact that the alleged disclosure misdemeanours would never have occurred had the company not opted to issue new shares in April 2008, seemingly at the height of its financial maelstrom. Otherwise, the accuracy and integrity of RBS's listing particulars would self-evidently not have been an issue. Accordingly, outside of this particular factual setting the continuing functionality of the director's duty of care should not yet be dismissed entirely: that is, at least not until the UK has witnessed a comparable oversight-related misinformation case within the secondary market context. ${ }^{119}$

Moreover, the precise extent to which securities law misinformation claims are capable of usurping corporate law duty of care actions in oversight-related scenarios in the UK is dependent on a number of additional factors. These include the feasibility of future civil-procedural reforms in England and Scotland, such as the potential introduction of contingency fees and/or opt-out class actions, geared to facilitating US-style multi-party securities litigation in the UK. ${ }^{120}$ Further consideration of these issues lies outside the scope of the present study. For now it suffices to say that, irrespective of one's view on the desirability (or otherwise) of relying on securities law mechanisms to redress traditional corporate law concerns, whether securities law has a significant long-term role to play in this regard will likely fall to a large extent upon broader systemic developments outside of the particular substantive areas of law in question.

\footnotetext{
${ }^{119}$ In this regard, it should be noted that under section 90A of FSMA 2000 (the UK's principal regulatory provision concerning civil liability for secondary market disclosure lapses), a defendant's liability is determined by recourse to the relatively onerous fraud standard, in contrast to the lower negligence threshold which in effect is applied in determining section 90 liability (i.e. for primary market misinformation). Furthermore, whilst section 90A liability for secondary market misinformation attaches only to the issuing corporate entity itself (and thus not to any of its individual directors or other responsible agents, as in the case of s. 90 liability), this does not preclude activation in such cases of the other indirect adverse consequences of litigation for directors referred to above, nor does it assure against the possibility of responsible corporate officers being individually subject to public enforcement proceedings by the Financial Conduct Authority in appropriate cases. On this, see nn. 59-62 above and accompanying text; Davies (2007), p 25; Cheffins and Black (2006), p 1467. On the relative significance of public (over private) securities law enforcement methods in the UK generally, see Ferran (2009); Jackson and Roe (2009).

${ }^{120}$ On these factors, see Sorabji et al. (2008); Taylor (2013); Warnot et al. (2011), pp 24-27; Armour et al. (2009), p 693.
} 
Subject to those (not-unimportant) provisos, though, it is anticipated that the relative practical significance of the director's duty of care in UK listed companies will in future continue to wither in line with corresponding experience in the United States; albeit that the anticipated British trend in this regard is, for the above reasons, likely to develop in a comparatively more gradual and stunted manner than its US counterpart.

\section{Conclusion}

In terms of the key lessons that can be learned from the above cases, one of the most striking is how seemingly very similar alleged fact patterns can be conducive to very different judicial or administrative findings, depending on the particular legal argument that those facts are advanced in support of. This is true nowhere more so than in the overlapping yet distinct field of Anglo-American corporate and securities law. Indeed, a common and remarkable feature of the RBS and Citigroup cases is that allegations of risk oversight failure which on their own were inadequate to ground a directors' duties complaint under corporate law, were nonetheless deemed sufficient in principle to sustain an alternative securities law action based on management's alleged provision of misleading information to investors.

Given the apparent functional substitutability of corporate and securities law claims in this context, and also the abovementioned practical advantages of the latter type of claim, one would not be rash in anticipating the progressive diminution of the director's corporate law duty of care as a recognised avenue of redress for UK investors in risk oversight failure scenarios. Certainly, such a development would seem to be underway in the United States, and recent events suggest that a similar trend is now tentatively in the making in the UK. However, notwithstanding its relegated status today within the broader corporate law architecture, it is arguable that the director's duty of care still has a material future role to play in AngloAmerican corporate governance, albeit on a largely expressive or symbolic level. That is to say, the traditional corporate law duty of care can still justify its continuing existence in this context, insofar as it purports to provide an authoritative and normatively salient statement of accepted public standards of conduct pertaining to senior officeholders in large business organisations. ${ }^{121}$ Indeed, this is arguably something that securities law provisions expressly pertaining to purely technical matters of managerial informational disclosure are inherently incapable of doing. Hence the director's duty of care will likely still matter to public company boards of the future, albeit in a softer and more functionally limited way than many corporate law scholars might be readily willing to admit.

In view of these considerations, the present article should therefore not be interpreted as any sort of clarion call to dispense with the director's duty of care as it applies within the public company context in either of the countries concerned. At

\footnotetext{
${ }^{121}$ On the capacity of law to exert an indirect educative effect by making 'statements' as opposed to determining social behaviour directly, see generally Sunstein (1996); and, in the specific context of directorial duty of care cases, see Allen et al. (2002).
} 
the very least, though, the above insights would suggest that teachers of UK and US corporate law can quite safely afford to curtail the level of attention that they customarily devote to this particular aspect of their subject, without doing any great deal of practical disservice to their students.

Open Access This article is distributed under the terms of the Creative Commons Attribution 4.0 International License (http://creativecommons.org/licenses/by/4.0/), which permits unrestricted use, distribution, and reproduction in any medium, provided you give appropriate credit to the original author(s) and the source, provide a link to the Creative Commons license, and indicate if changes were made.

\section{References}

Allen WT, Jacobs JE, Strine LB (2002) Realigning the standard of review of director due care with Delaware public policy: a critique of Van Gorkom and its progeny as a standard of review problem. Northwest Univ Law Rev 96:449-466

Armour J, Black B, Cheffins B, Nolan R (2009) Private enforcement of corporate law: an empirical analysis of the United Kingdom and the United States. J Empir Leg Stud 6:687-722

Bainbridge SM (2004) The business judgment rule as abstention doctrine. Vanderbilt Law Rev 57:83-132 Bainbridge SM (2009) Caremark and enterprise risk management. J Corp Law 34:967-990

Bainbridge SM (2012) Corporate governance after the financial crisis. OUP, Oxford

Bebchuk LA (1992) Federalism and the corporation: the desirable limits on state competition in corporate law. Harv Law Rev 105:1435-1510

Berle AA, Means G (1932) The modern corporation and private property. Harcourt, Brace \& World, New York

Black BS, Cheffins BR, Klausner M (2006a) Outside director liability. Stan Law Rev 58:1055-1160

Black BS, Cheffins BR, Klausner M (2006b) Outside director liability: a policy analysis. J Inst Theor Econ 162:5-20

Bratton WW, Wachter ML (2011) The political economy of fraud on the market. Univ Penn Law Rev 160:69-168

Cheffins BR (2009) Did corporate governance 'fail' during the 2008 stock market meltdown? The case of the S\&P 500. Bus Lawyer 65:1-67

Cheffins BR, Black BS (2006) Outside director liability across countries. Tex Law Rev 84:1385-1480

Coffee JC (2006) Reforming the securities class action: an essay on deterrence and its implementation. Colum Law Rev 106:1534-1586

Davies P (2007) Davies review of issuer liability: liability for misstatements to the market. HM Treasury, London

Ferran E (2009) Are US-style investor suits coming to the UK? JCLS 9:315-348

Financial Conduct Authority and Prudential Regulation Authority (FCA/PRA) (2015) The failure of HBOS plc (HBOS). FCA/PRA, London

Financial Services Authority (FSA) (2011) The failure of the Royal Bank of Scotland. FSA, London

Fisch JE (2009) Confronting the circularity problem in private securities litigation. Wis Law Rev 2009:333-350

Fleischer (1965) Federal corporation law. Harv Law Rev 78:1146-1179

Gevurtz FA (2010) The role of corporate law in preventing a financial crisis: reflections on In re Citigroup Inc., Shareholder Derivative Litigation. Glob Bus Dev Law J 23:113-156

Hill CA, McDonnell BH (2013) Reconsidering board oversight duties after the financial crisis. Univ Ill Law Rev 2013:859-880

House of Commons Treasury Committee (2008) The run on the rock, vol I. The Stationery Office Ltd, London

Jackson HE, Roe MJ (2009) Public and private enforcement of securities laws: resource-based evidence. J Financ Econ 93:207-238

Keay AR, Loughrey JM (2015) The framework for board accountability in corporate governance. Leg Stud 35:252-279 
Langevoort DC (2001) Seeking sunlight in Santa Fe's shadow: the SEC's pursuit of managerial accountability. Wash Univ Law Q 79:449-490

Langevoort DC (2009) Basic at twenty: rethinking fraud-on-the-market. Wis Law Rev 2009:151-198

Loughrey JM (2012a) Introduction. In: Loughrey JM (ed) Directors' duties and shareholder litigation in the wake of the financial crisis. Edward Elgar, Cheltenham

Loughrey JM (2012b) The director's duty of care and skill and the financial crisis. In: Loughrey JM (ed) Directors' duties and shareholder litigation in the wake of the financial crisis. Edward Elgar, Cheltenham, ch 1

Loughrey JM (2012c) Conclusion. In: Loughrey JM (ed) Directors' duties and shareholder litigation in the wake of the financial crisis. Edward Elgar, Cheltenham, ch 8

Lowry J, Lowry J, Edmunds R (2015) Directors' duties and liabilities: disqualifying 'unfit' directors at banks? Political rhetoric and the directors' disqualification regime. In: Chiu HY, McKee M (eds) The law on corporate governance in banks. Edward Elgar, Cheltenham, ch 3

Miller RT (2010) The board's duty to monitor risk after Citigroup. Univ Pa J Bus Law 12:1153-1168

Moore MT (2010) The evolving contours of the board's risk management function in UK corporate governance. JCLS 10:279-308

Moore MT (2013) Corporate governance in the shadow of the state. Hart, Oxford

Moore MT (2015) The (neglected) value of board accountability in corporate governance. LFMR 9:10-18

Moore MT (2017) The de-privatisation of Anglo-American corporate law? In: Tomasic R (ed) Routledge handbook of corporate law. Routledge, London, ch 2

Pan EJ (2011) Rethinking the board's duty to monitor: a critical assessment of the Delaware doctrine. Fla State Univ Law Rev 38:209-250

Parliamentary Commission on Banking Standards (2013) 'An accident waiting to happen': the failure of HBOS. The Stationery Office Ltd, London

Romano R (1993) The genius of American corporate law. AEI Press, Washington, DC

Romano R (2005) The Sarbanes-Oxley Act and the making of quack corporate governance. Yale Law J 114:1521-1611

Sorabji J, Napier M, Musgrove R (eds) (2008) Improving access to justice through collective actions: final report. Civil Justice Council, London

Sunstein CR (1996) On the expressive function of law. Univ Penn Law Rev 144:2021-2054

Taylor JA (2013) Taylor review: review of expenses and funding of civil litigation in Scotland. Edinburgh. http://www.gov.scot/Publications/2013/10/8023/5. Accessed 1 September 2017

Thompson RB, Sale HA (2003) Securities fraud as corporate governance: reflections upon federalism. Vanderbilt Law Rev 56:859-910

Tomasic R (2008) Corporate rescue, governance and risk taking in Northern Rock: part 2. Comp Law 29:330-337

Velikonja U (2015) Team production and securities laws. Seattle Univ Law Rev 38:725-737

Walker D (2009) A review of corporate governance in UK banks and other financial industry entities: final recommendations. The Walker Review Secretariat, London

Warnot J, Strik D, Malaga F (2011) Collective actions across the globe-a review. Linklaters, London

Wu JY (2006) Revisiting business roundtable and section 19(c) in the wake of the Sarbanes-Oxley Act. Yale J on Regul 23:249-268 